Southern Illinois University Carbondale

OpenSIUC

Articles

Department of Plant, Soil, and Agricultural Systems

$11-2011$

\title{
Performance of coiled tube ultraviolet reactors to inactivate Escherichia coli W1485 and Bacillus cereus endospores in raw cow milk and commercially processed skimmed cow milk
}

Ruplal Choudhary

Southern Illinois University Carbondale, choudhry@siu.edu

Srinivasaro Bandla

Southern Illinois University Carbondale

Dennis G. Watson

Southern Illinois University Carbondale, dwatson@siu.edu

John Haddock

Southern Illinois University Carbondale

Amer Abughazaleh

Southern Illinois University Carbondale, aabugha@siu.edu

See hift put pagefor additionalquthors

(C)2011. This manuscript version is made available under the CC-BY-NC-ND 4.0 license http://creativecommons.org/licenses/by-nc-nd/4.0/

\section{Recommended Citation}

Choudhary, Ruplal, Bandla, Srinivasaro, Watson, Dennis G., Haddock, John, Abughazaleh, Amer and Battacharya, Bhaskar. "Performance of coiled tube ultraviolet reactors to inactivate Escherichia coli W1485 and Bacillus cereus endospores in raw cow milk and commercially processed skimmed cow milk." Journal of Food Engineering 107, No. 1 (Nov 2011): 14-20. doi:10.1016/ j.jfoodeng.2011.06.009.

This Article is brought to you for free and open access by the Department of Plant, Soil, and Agricultural Systems at OpenSIUC. It has been accepted for inclusion in Articles by an authorized administrator of OpenSIUC. For more information, please contact opensiuc@lib.siu.edu. 
Authors

Ruplal Choudhary, Srinivasaro Bandla, Dennis G. Watson, John Haddock, Amer Abughazaleh, and Bhaskar Battacharya 
Performance of coiled tube ultraviolet reactors to inactivate Escherichia coli W1485 and Bacillus cereus endospores in raw cow milk and commercially processed skimmed cow milk

a Department of Plant, Soil and Agricultural Systems, 1205 Lincoln Drive, Room 176, Mailcode 4415, Southern Illinois University, Carbondale, IL 62901 USA

${ }^{\mathrm{b}}$ Department of Microbiology, Room 131, Life Science II, 1125 Lincoln Drive, Southern Illinois University, Carbondale, IL 62901 USA

${ }^{c}$ Department of Animal Science, Food \& Nutrition, 1205 Lincoln Drive, Mail Code 4417, Southern Illinois University Carbondale, IL 62901 USA

${ }^{\mathrm{d}}$ Department of Mathematics, Neckers Building, Room A 269, Southern Illinois University, Carbondale, IL 62901 USA

*Corresponding author. Department of Plant, Soil and Agricultural Systems, 1205 Lincoln Drive, Room 176, Mailcode 4415, Southern Illinois University, Carbondale, IL 62901, USA. Phone: 618453 6985, FAX: 618453 7457, Email: choudhry@ siu.edu

\begin{abstract}
Two coiled tube reactors were designed to investigate the influence of Reynolds number $\left(\mathrm{R}_{\mathrm{e}}\right)$ and diameter of fluid carrying tube on UV-C inactivation of Escherichia. coli W1485 and Bacillus cereus endospores in raw cow milk (RCM) and skimmed cow milk (SCM) at room temperature. UV reactors were constructed using perfluoroalkoxy (PFA) tubing having internal diameters of $1.6 \mathrm{~mm}$ and $3.2 \mathrm{~mm}$ and each had a residence time of $11.3 \mathrm{~s}$. Four levels of $\mathrm{R}_{\mathrm{e}}$ were tested for each milk type, each tube size and each bacteria type. Inactivation efficiency increased as the $\mathrm{R}_{\mathrm{e}}$ increased in both the reactors for both types of milk. The inactivation of both bacteria was higher in the $1.6 \mathrm{~mm}$ UV reactor than the $3.2 \mathrm{~mm}$ UV reactor. Maximum reduction of $7.8 \log _{10} \mathrm{CFU} / \mathrm{ml}$ of $E$. coli was achieved in SCM in the $1.6 \mathrm{~mm}$ UV reactor corresponding to the $\mathrm{R}_{\mathrm{e}}$ of 532 and higher, whereas the maximum reduction of E.coli in RCM was $4.1 \log _{10} \mathrm{CFU} / \mathrm{ml}$ at the highest level of $\mathrm{R}_{\mathrm{e}}$ (713) tested. For B.cereus, the maximum reduction was $2.72 \log _{10} \mathrm{CFU} / \mathrm{ml}$ in $1.6 \mathrm{UV}$ reactor, in SCM at $\mathrm{R}_{\mathrm{e}}$ of 1024; whereas the maximum reduction of B.cereus in RCM was 2.65 $\log _{10} \mathrm{CFU} / \mathrm{ml}$ at $\mathrm{R}_{\mathrm{e}}$ value of 713. Inactivation efficiency of both bacteria was more in SCM than $\mathrm{RCM}$. The coiled tube reactor design provided adequate mixing and UV-C dosage for efficient disinfection of E.coli cells in milk.
\end{abstract}

Keywords: Ultraviolet C, ultraviolet reactor, nonthermal processing, cow milk, E.coli, B. cereus. 


\section{Introduction}

Thermal processing of foods has been the most popular technology for food preservation. denaturation, loss of nutrients and vitamins (Wirjantoro and Lewis, 1997; Knorr, 1999). Moreover, reports suggest raw dairy products are preferred by consumers due to superior organoleptic characteristics (Buchin et al., 1998). Therefore there is an emphasis on developing nonthermal processing technologies with the goal of improving retention of quality and nutrition of food products (Knorr, 1999; IFT, 1999). Ultraviolet (UV) irradiation is one nonthermal technology that has garnered considerable interest for treatment of food.

Within the UV range, there are three regions based on the wave lengths in the electromagnetic spectrum: UV-A (315 - 400nm), UV-B (280 - 315nm) and UV-C (200 - 280nm). Studies (Bank et al., 1990; Miller et al., 1999) suggest the destruction of microorganisms occurs by penetration of UV-C light through the cell membrane resulting in damage of DNA due to the formation of thymine dimers which prevent DNA transcription and replication, eventually leading to cell death. The $253.7 \mathrm{~nm}$ in the UV-C region was reported to have the most efficient bactericidal effect because the DNA of microorganisms absorbs photons strongly at this wavelength (Harm, 1980).

When UV is used to treat food, the UV-C dose is the radiant UV-C energy incident on a unit surface area of food being treated. UV-C dose is normally calculated using the following equation (Quintero-Ramos et al., 2004).

UV-C dose $\left(\mathrm{mJ} / \mathrm{cm}^{2}\right)=$ Irradiance intensity $\left(\mathrm{mW} / \mathrm{cm}^{2}\right) \times$ Exposure time $(\mathrm{s})$

Where, Irradiance intensity is the incident intensity of UV-C light on the surface being treated. It may be either directly measured using a UV-C sensor or estimated if the intensity of the source and optical properties of transmission medium in known.

Different types of ultraviolet reactors for liquid food pasteurization have been reported in literature. Wright et al. (2000) used a commercial thin film UV reactor (CIDER-10uv) to inactivate Escherichia coli $\mathrm{O} 157: \mathrm{H} 7$ in apple cider by $3.8 \log _{10} \mathrm{CFU} / \mathrm{ml}$ with a UV dose of 9.4 to $61.0 \mathrm{~mJ} / \mathrm{cm}^{2}$. Using another brand of a thin film UV reactor (CiderSure3500A), Hanes et al. (2002) reported the reduction of Cryptosporidium parvum oocysts by $6 \log _{10} \mathrm{CFU} / \mathrm{ml}$ in apple cider at the UV dose of $14.32 \mathrm{~mJ} / \mathrm{cm}^{2}$. The earliest use of a coiled tube UV reactor for food treatment was reported by Geveke (2005) to reduce bacterial loads in apple cider. The author reported a reduction of E.coli $\mathrm{K} 12$ by $3.4 \log _{10} \mathrm{CFU} / \mathrm{ml}$. Using another coiled tube UV reactor, Koutchma et al. (2007) studied inactivation of E. coli K12 in pineapple, guava, apples, and lilikoi juices and reported 5- $\log _{10} \mathrm{CFU} / \mathrm{ml}$ reductions of $E$. coli $\mathrm{K}-12$ in juices with absorption coefficient less than $15 \mathrm{~cm}^{-1}$. Franz et al. (2009) also used a coiled tube UV reactor (UVivatec) and reported inactivation of E. coli and Lactobacillus brevis in cloudy apple juice to below detectable limits from an inoculum level of $10^{6} \mathrm{CFU} / \mathrm{ml}$ or $10^{4} \mathrm{CFU} / \mathrm{ml}$.

A few studies have reported using UV-C to ensure microbial safety of goat milk and raw cow milk (RCM) of different fat percentages (Matak, 2004; Matak et al., 2005; Reinemann et al., 2006). With goat milk, greater than $5-\log _{10} \mathrm{CFU} / \mathrm{ml}$ reduction of Listeria monocytogenes was achieved at a cumulative UV-C dose of $15.8 \pm 1.6 \mathrm{~mJ} / \mathrm{cm}^{2}$ under turbulent flow conditions for a cumulative exposure time of $18 \mathrm{sec}$ in a thin film UV reactor (Cider Sure 3500) (Matak et al., 2005). Using the same machine, Matak (2004) found efficacy of UV-C on inactivation of E. coli 
ATCC 25922 (an E. coli O157:H7 surrogate) was highest with skimmed cow milk (SCM) (2.27 logs) followed by reduced fat milk (1.82 logs) and whole milk (1.44 logs) at different temperatures under laminar flow conditions. Matak (2004) reported the reduction of the E. coli O157:H7 surrogate in whole milk treated with UV-C at $4^{\circ} \mathrm{C}$ was significantly lower than milk treated at $20^{\circ} \mathrm{C}$. Employing a turbulent flow UV reactor, UV-C was also reported to inactivate background flora present in the raw cow milk by $2.29 \log _{10} \mathrm{CFU} / \mathrm{ml}$ of SPC, $2.55 \log _{10} \mathrm{CFU} / \mathrm{ml}$ of psychrotrophs, and $1.67 \log _{10} \mathrm{CFU} / \mathrm{ml}$ of thermodurics (Reinemann et al., 2006).

Flow regime plays a role in killing microorganisms using continuous flow UV reactors for treating liquid foods (Koutchma et al., 2007; Matak, 2004; Matak et al., 2005). Reynolds number $\left(R_{\mathrm{e}}\right)$ is the ratio of inertial forces to viscous forces and is expressed as:

$R_{\mathrm{e}}=(\rho / \mu) \times v D$

where, $R_{\mathrm{e}}$ is Reynolds number, $\rho$ is density of fluid, $\mu$ is dynamic viscosity of fluid, $D$ is diameter of tube carrying the fluid, and $v$ is velocity of flow (Geankoplis, 1993).

Laminar flow occurs when $R_{e}<2100$, whereas $R_{e}>4000$ indicates turbulent flow. A flow regime with $R_{e}$ between these numbers is considered transient flow (Geankoplis, 1993). The flow pattern of a fluid in a coiled tube is known as Dean flow (Dean 1927). A secondary flow field accompanies laminar flow of fluid as centrifugal forces act on the fluid within the coiled tube. The Dean number $D_{\mathrm{e}}$ is the similarity parameter governing the fluid motion in coiled tube flow configuration.

$D_{e}=R_{\mathrm{e}} \sqrt{ }\left(D / D_{\mathrm{c}}\right)$

where $D$ is the tube diameter, $D_{\mathrm{c}}$ is the coil diameter, and $R_{\mathrm{e}}$ is the tube Reynolds number (Dean 1927). According to Dean's (1927) theory, the secondary flow vortices occur in the range of 0.03 $<\mathrm{D} / \mathrm{D}_{\mathrm{c}}<0.10$. Koutchma et al. (2004) suggested that flow pattern and design of the UV reactor are critical factors for treatment of any liquid with UV-C. In a coiled tube UV reactor with Dean flow conditions, secondary flow vortices provide uniform mixing conditions of fluid particles, improving UV-C exposure (Koutchma et al., 2007; Franz et al., 2009).

There were outbreaks of $E$. coli $\mathrm{O} 157: \mathrm{H} 7$ in California, Washington, and Ohio due to consumption of RCM in 2006 (Int. Soc. for Infectious Diseases, 2006). In the study reported here, E. coli $\mathrm{W} 1485$ was used as a surrogate of $E$. coli $\mathrm{O} 157: \mathrm{H} 7$ as a safety precaution. Bachmann (1972) reported that $E$. coli $\mathrm{W} 1485$ is related to $E$. coli $\mathrm{K}-12$ strains. The strain is reported to be more resistant to UV-C than the pathogenic strain O157:H7 (Murakami et al., 2005). Thus, treatments that inactivate strain W 1485 would be expected to be more effective with the pathogen.

Endospores produced by some Gram positive may survive pasteurization and cause processing problems for the dairy industry. Survival of endospores is a limiting factor for the shelf life of pasteurized milk. For example, Bacillus cereus is a potential food poisoning agent that can survive pasteurization and limit the shelf life of the fluid milk products (Magnusson et al., 2007).

Bandla (2010) evaluated $E$. coli W1485 inactivation in inoculated milk with a coiled tube $\mathrm{UV}$ reactor at different flow rates to determine a minimum residence time for a $5-\log 10 \mathrm{CFU} / \mathrm{ml}$ reduction. The flow rates ranged from $25 \mathrm{ml} / \mathrm{min}$ to $100 \mathrm{ml} / \mathrm{min}$. The $E$. coli was inactivated by more than $8.5 \log _{10} \mathrm{CFU} / \mathrm{ml}$ at flow rates up to $75 \mathrm{ml} / \mathrm{min}$, corresponding with a minimum residence time of $11.3 \mathrm{~s}$.

The objectives of this study was to design two coiled tube UV reactors for experimental purposes and examine their efficiency on inactivation of E. coli W 1485 and B. cereus spores in $\mathrm{RCM}$ and SCM. The effects of Reynolds number $\left(\mathrm{R}_{\mathrm{e}}\right)$ and tube diameter with a constant 
residence time of the milk product inside the UV reactor were investigated. A design consideration was for the two UV reactors to be identical except for tube size and tube length, and for the UV reactor with the smaller diameter tube to have Dean flow and the other to be as near Dean flow as possible.

\section{Materials and Methods}

\subsection{UV reactors}

Two UV reactors were designed for this study (Figure 1). The UV-C source for each was a $8.7 \mathrm{~W}, 110 \mathrm{~V}$, UV-C germicidal lamp with peak emission at $253.7 \mathrm{~nm}$, having a $505 \mathrm{~mm}$ arc length and $15 \mathrm{~mm}$ outside diameter (OD) (SBL325, American Ultraviolet Company, Lebanon, IN, USA). The UV lamp was enclosed within a quartz glass sleeve (American Ultraviolet Company, Lebanon, IN, USA) with a $22 \mathrm{~mm}$ OD and an air gap of $2.4 \mathrm{~mm}$ between UV lamp and sleeve. Perfluoroalkoxy polymer resin (PFA) tubing was selected to wrap around the UV reactor based on Geveke's report (Geveke, 2008) that PFA tubing is highly transparent to UV light and has more chemical and heat resistance than polytetrafluoroethylene and fluorinated ethylene propylene. One UV reactor was designed using $1.6 \mathrm{~mm}$ inside diameter (ID) by $3.2 \mathrm{~mm}$ OD PFA tubing, hereafter called the 1.6 UV reactor. Another UV reactor was designed using 3.2 $\mathrm{mm}$ ID by $4.8 \mathrm{~mm}$ OD PFA tube, hereafter called the $3.2 \mathrm{UV}$ reactor. PFA tubing was wrapped in the form of coils around the UV lamp sleeve. Both UV reactors were covered with aluminum foil to prevent exposure to the personnel of UV light.

A range of $R_{e}$ was required for this study and was achieved by using different flow rates of milk through the UV reactors and calculating the resulting $\mathrm{R}_{\mathrm{e}}$, based on equation 2 (Table 1). The density $(\rho)$ and viscosity $(\mu)$ of RCM and SCM milk was estimated according to the relationship developed by Bakshi and Smith (1984). RCM had a lower density $(\rho=1021.46$ $\left.\mathrm{kg} / \mathrm{m}^{3}\right)$ and higher dynamic viscosity $\left(\mu=1.941 \times 10^{-3} \mathrm{Ns} / \mathrm{m}^{2}\right)$ than SCM $\left(\rho=1024.34 \mathrm{~kg} / \mathrm{m}^{3}\right.$ and $\left.\mu=1.314 \times 10^{-3} \mathrm{Ns} / \mathrm{m}^{2}\right)$. This resulted in a higher kinematic viscosity $(\mu / \rho)$ in $\operatorname{RCM}\left(1.9 \times 10^{-6}\right.$ $\left.\mathrm{m}^{2} / \mathrm{s}\right)$ than $\mathrm{SCM}\left(1.27 \times 10^{-6} \mathrm{~m}^{2} / \mathrm{s}\right)$ and lower $\mathrm{R}_{\mathrm{e}}$ for $\mathrm{RCM}$.

In order to maintain a consistent residence time of product exposure to $\mathrm{UV}$, different lengths of tubing were used for each flow rate (and corresponding $\mathrm{R}_{\mathrm{e}}$ ). A residence time of $11.3 \mathrm{~s}$ was selected based on the work of Bandla (2010).

The PFA tubing wrapped around the quartz glass sleeve was divided into two zones in both reactors (Figure 1). For the 1.6 UV reactor, the length of the tubing wrapped in the first zone was $240 \mathrm{~cm}$ and the second zone was $480 \mathrm{~cm}$. For the $3.2 \mathrm{UV}$ reactor, the length of the first zone of the tubing was $120 \mathrm{~cm}$ and the second zone was $240 \mathrm{~cm}$. A three-way valve connected the two divided zones in each UV reactor, allowing flow through each zone only or through both zones. Four levels of $R_{e}$ were achieved by changing the flow rate of milk in each reactor while keeping the residence time constant by allowing fluid flow through the first zone only, second zone only, first and second zone, and first and second zone with recirculation through the first zone. The recirculation was provided in a two step process. First, milk was pumped through the zone $1+2$ and milk was collected, and then the collected milk was pumped through the zone 1 only. See Table 1 for a listing of length of PFA tubing for each $R_{e}$ and flow rate. Using this arrangement, residence time of milk in the both reactors was the same at all levels of $R_{e}$. Flow rate was doubled for the 3.2 UV reactor compared to the $1.6 \mathrm{UV}$ reactor at each $\mathrm{R}_{\mathrm{e}}$ level to achieve the same $R_{e}$ at each level in both UV reactors. 
The UV-C dose was calculated using equation (1) by multiplying the residence time (11.3 s) with the irradiance intensity at the milk surface. The irradiance intensity was estimated by multiplying the UV-C intensity of the lamp at $5 \mathrm{~mm}$ from the lamp $\left(1.375 \mathrm{~mW} / \mathrm{cm}^{2}\right)$ with the transmittance of quartz glass sleeve $(90 \%)$ and PFA tube ( $80 \%$ in germicide range). Using these values, the estimated UV-C dose for the designed reactors was $11.187 \mathrm{~mJ} / \mathrm{cm}^{2}$.

\subsection{Calibration of flow rate in $U V$ reactor}

Prior to the experiments, the flow rates of RCM and SCM through the UV reactors were calibrated at 25, 50, 75 and $100 \mathrm{ml} / \mathrm{min}$ with the $1.6 \mathrm{UV}$ reactor; and 50, 100, 150 and 200 $\mathrm{ml} / \mathrm{min}$ with the $3.2 \mathrm{UV}$ reactor. These flow rates produced different $\mathrm{R}_{\mathrm{e}}$ levels (Table 1). During calibration, the inlet and outlet temperatures of milk were observed to be in the range of 23 $24^{\circ} \mathrm{C}$ and $24-26^{\circ} \mathrm{C}$, respectively. This temperature range was selected because the earlier studies reported a better kill rate at room temperature compared to that of the $4^{\circ} \mathrm{C}$ (Matak, 2004). Each type of milk $(500 \mathrm{ml})$ was pumped through each UV reactor and collected in a graduated cylinder for $1 \mathrm{~min}$ with three replicates. The setting of peristaltic pump speed at each flow rate was recorded and a linear regression equation $\left(R^{2}=0.98\right.$ for $R C M$ and $R^{2}=0.94$ for $\left.S C M\right)$ was determined and used to set the pump speed setting.

During actual experiments, the pump speed dial was set per the respective regression equation. Actual flow rates were also measured during the experiments using a timer and a graduated cylinder. The difference between actual flow rates from the planned flow rates was \pm 1 $\mathrm{ml} / \mathrm{min}$ at the set pump speed.

\subsection{Milk collection}

Fresh RCM was collected in an autoclaved glass bottle from the dairy farm of Southern Illinois University, Carbondale. Milk composition (fat, protein and total solids) was analyzed using an infrared analyzer (Infrared Analyzer, Denver Instrument Company, Arvado, CO) by the lab technicians of Prairie Farms (Carbondale, IL, 62901). Skimmed milk was purchased from a local grocery store. The milk samples were refrigerated until UV processing, about 5 - $6 \mathrm{~h}$ later.

\subsection{Milk quality}

Natural background floras were enumerated in RCM and SCM by standard plate count (SPC) and coliform count (Wehr and Frank, 2004). Dilution blanks were made up of phosphatebuffered saline (PBS). A series of dilutions were spread plated $(0.1 \mathrm{ml})$ in duplicate onto tryptic soy agar (TSA) (Difco Laboratories, Detroit, MI). Plates were incubated at $33^{\circ} \mathrm{C}$ for $24-48$ hours. Natural presence of E. coli cells in RCM was assessed as per Marshall (2004) by using selective media namely, violet red bile agar (VRBA) with methylumbelliferyl- $\beta$-D-glucuronide (MUG) (Difco Laboratories, Detroit, MI).

\subsection{Optical absorbance}

UV-C absorbance of RCM and SCM was measured at $24-25^{\circ} \mathrm{C}$ with a UV-visible spectrophotometer (UV-1601, Shimadzu, Columbia, MD) at $254 \mathrm{~nm}$ wavelength by diluting each milk sample to $99 \%$ with deionized water. Since milk samples were not very transparent to UV$\mathrm{C}$, it was not possible to get absorbance reading. Therefore the samples were diluted and the resultant absorption coefficient values were multiplied by 100 to obtain estimated absorption coefficient of undiluted SCM and RCM. Disposable polystyrene cuvettes (Fisher Scientific) with a path length of $10 \mathrm{~mm}$ were used to measure the absorbance. The absorption coefficient was 
determined as the ratio of absorbance of milk to path length of the cuvette used to measure the absorbance.

\section{6. pH test}

A pH meter (Corning, NY, USA) was calibrated using buffer solutions before measuring $\mathrm{pH}$ in both types of milk. With milk temperature at $24-25^{\circ} \mathrm{C}, \mathrm{pH}$ was measured three times for each type of milk.

\section{7. $E$. coli W1485 culture preparation}

Stock cultures of $E$. coli W1485 were obtained from Dr. David P. Clark, Department of Microbiology, Southern Illinois University, Carbondale, IL. A colony was picked with a sterilized wire loop from the stock culture. This colony was inoculated in $120 \mathrm{ml}$ tryptic soy broth (TSB) and incubated in a gyratory water bath shaker (New Brunswick Scientific Edison, NJ, USA) at $34^{\circ} \mathrm{C}$ for 18 - 24 hours (Marshall 2004). Serial dilutions were made and $0.1 \mathrm{ml}$ of each dilution was spread plated onto TSA plates for estimating the cells present in the $120 \mathrm{ml}$ TSB after incubation. These plates were incubated at $33^{\circ} \mathrm{C}$ for 18 - 24 hours and enumeration was determined by counting the colony forming units (CFU). An agar plate containing media without spread plating was also incubated at the same incubation temperature to assess if the poured media in petri plates was contaminated. The culture obtained from TSB was centrifuged (Beckman J2-M1, Schaumburg, IL, USA) at $12,000 \mathrm{rpm}$ for $15 \mathrm{~min}$ at $4^{\circ} \mathrm{C}$ and the supernatant was discarded (Krishnamurthy et al. 2007). The pellet was immediately mixed with milk samples as described in section $\mathbf{2 . 9}$.

\subsection{B. cereus endospore preparation}

B. cereus (ATCC Preceptrol ${ }^{\circledR}$ strain) was obtained from a $-70^{\circ} \mathrm{C}$ glycerol stock supplied by the Department of Microbiology, Southern Illinois University, Carbondale, IL. Endospores of B. cereus were prepared according to Beuchat et al. (1997). Briefly, a pure-culture was inoculated into nutrient broth (Difco) and incubated at $30^{\circ} \mathrm{C}$. Three successive loop transfers at $24 \mathrm{~h}$ intervals were made before spreading $0.1 \mathrm{ml}$ aliquots onto the sporulation medium (Nutrient agar, Difco) supplemented with $0.05 \mathrm{~g}$ of $\mathrm{MnSO}_{4}$ per liter. The plates were incubated for $72 \mathrm{~h}$ at $30^{\circ} \mathrm{C}$ and the spores were harvested by depositing $5 \mathrm{ml}$ of sterile distilled water on the surface of each plate and rubbing gently with a sterile bent glass rod. The washing procedure was repeated twice. The resultant wash suspensions were centrifuged at $3000 \mathrm{rpm}$ for $20 \mathrm{~min}$ at $5^{\circ} \mathrm{C}$ (Beckman J2-M1, Schaumburg, IL, USA) and the supernatant liquid was discarded. The resulting pellet was suspended in $100 \mathrm{ml}$ of sterile distilled water and centrifuged at 6,000 rpm for $10 \mathrm{~min}$ at $5^{\circ} \mathrm{C}$. This procedure was repeated twice and the final pellet was suspended in sterile de-ionized water and $5 \mathrm{ml}$ each were distributed in $15 \mathrm{ml}$ sterile centrifuge tubes. The tubes were placed in a water bath at $80^{\circ} \mathrm{C}$ for $30 \mathrm{~min}$ to kill vegetative cells (Beuchat et al., 1997). After $30 \mathrm{~min}$ holding time at $80^{\circ} \mathrm{C}$, the centrifuge tubes were stored in a cold room at $4{ }^{\circ} \mathrm{C}$ to inhibit further growth. Gram stains of the endospore preparation were observed with a light microscope for the presence of vegetative cells. After making sure all the vegetative cells were destroyed by the heat treatment process, $5 \mathrm{ml}$ spores contained in centrifuge tubes were stored in a cold room at $4{ }^{\circ} \mathrm{C}$ to inhibit the further growth of vegetative cells. These centrifuge tubes were used in the subsequent experiments.

\subsection{Inoculation of $E$. coli $W 1485$ and $B$. cereus spores}

Pyrex glass bottles $(2000 \mathrm{ml})$ with a magnetic stirrer were autoclaved and filled with $1500-1600 \mathrm{ml}$ of the refrigerated RCM and SCM in separate bottles. An E. coli W1485 pellet 
obtained from a $120 \mathrm{ml}$ culture was directly added to each RCM and SCM container. This inoculated milk served as the source of milk that was treated in the reactors. The milk was slowly stirred with a stirrer for 30 min to warm the milk to room temperature $\left(23-24^{\circ} \mathrm{C}\right)$ prior to sampling for microbial enumeration and UV-C treatment. Samples for microbial counts were serially diluted and $0.1 \mathrm{ml}$ was spread plated onto petri plates containing VRBA with MUG (Difco Laboratories, Detroit, MI). VRBA with MUG is a selective medium to estimate the $E$. coli cells present in milk (Marshall 2004). This medium can differentiate $E$. coli from other species of coliforms by observing pink-colored $E$. coli colonies under long-wavelength UV light (Marshall 2004).

Sterile glass containers $(2000 \mathrm{ml})$ were separately filled with $1500-1600 \mathrm{ml}$ of RCM and SCM and inoculated with $5 \mathrm{ml}$ of a B. cereus endospore preparation (see 2.8 above). The containers were slowly stirred on a magnetic stirrer for 15 - $20 \mathrm{~min}$ to suspend endospores uniformly in each milk type and then used for enumeration and UV-C treatment as described for E. coli. B. cereus endospores in the RCM and SCM were estimated using Mannitol egg yolk polymyxin agar (MYPA) (Beuchat et al. 1997). Sterile egg yolk and polymyxin vials were used to prepare MYPA media according to the manufacturer's directions (Difco Laboratories, Detroit, MI) (Donovan, 1958). Enumeration of microorganisms in untreated and treated milk samples was performed using plate counts as described in sections 2.7 and 2.8.

\subsection{UV reactor operation and cleaning}

Inoculated milk samples were treated using the UV reactors. A milk temperature of 24 $26^{\circ} \mathrm{C}$ was observed during each of the experiments. The UV lamp was turned on three minutes before pumping milk through the reactors. The pump speed of the peristaltic pump was set per the calibrated settings to provide proper flow rates for each $R_{e}$. The milk sample $(500 \mathrm{ml})$ was pumped through the reactor until all $500 \mathrm{ml}$ was finished. In case of $4^{\text {th }}$ level of Re, all $500 \mathrm{ml}$ milk was pumped through the reactor once more, this time through zone 1 only. Treated milk samples were collected in sterile bottles and immediately stored in a cold room $\left(4^{\circ} \mathrm{C}\right)$. Treated milk samples $(0.1 \mathrm{ml})$ were spread plated on agar plates and incubated at $32-35^{\circ} \mathrm{C}$. The control samples were prepared by pumping the inoculated milk samples through the reactors while the UV lamp was turned off. The same counting procedure used for the controls was applied to the treated milk.

Both UV reactors were cleaned immediately after each treatment by pumping hot water $(500 \mathrm{ml})$ at $70^{\circ} \mathrm{C}$ followed by $100 \mathrm{ml}$ hypochlorite recirculation $(200 \mathrm{ppm})$ for $10 \mathrm{~min}$, followed by $100 \mathrm{ml}$ ethyl alcohol (95\%) recirculation for $4 \mathrm{~min}$ and a final rinse with sterile $500 \mathrm{ml}$ deionized water at room temperature. The final rinse water was collected in a sterile test tube and spread plated directly onto TSA plates to examine the efficacy of the cleaning procedure. After cleaning the UV reactors with the above procedure, there were fewer survivors than the limit of detection $(10 \mathrm{CFU} / \mathrm{ml})$ in either reactor.

\subsection{Experimental design and statistical analysis}

Factorial experimental design was used for this study. UV reactor (tubing diameter) and $\mathrm{R}_{\mathrm{e}}$ were the main effects and $\log$ reduction of the bacteria was the dependent variable. Each of the four combinations of milk type (RCM and SCM) and bacteria (E.coli and B. cereus) was a separate experiment. The UV reactor variable treatments were $1.6 \mathrm{UV}$ reactor and $3.2 \mathrm{UV}$ reactor. The four levels of $\mathrm{R}_{\mathrm{e}}$ for each of RCM and SCM are listed in Table 1. Each experiment consisted of eight treatments ( 2 UV reactors by $4 \mathrm{R}_{\mathrm{e}}$ levels), which were completed in a randomized order and replicated three times. 
The results of each experiment were analyzed separately with factorial ANOVA $(\alpha=$ 0.05) using proc GLM in SAS 9.2 software (SAS, 2008). If the interaction of the main effects was significant, the simple effects of $R_{\mathrm{e}}$ within each UV reactor and the simple effects of $U V$ reactor within each Re were determined. The $F$ value for the simple effect was computed per O'Rourke et al. (2005). Tukey's studentized range test was used to determine differences among means of significant effects.

\section{Results and Discussion}

\subsection{UV Reactors}

UV reactors were constructed with two sizes of tubing: $1.6 \mathrm{~mm}$ ID and $3.2 \mathrm{~mm}$ ID. The coil diameter of the 1.6 UV reactor and the $3.2 \mathrm{UV}$ reactor were $26 \mathrm{~mm}$ and $28 \mathrm{~mm}$, respectively. The calculated $\mathrm{D} / \mathrm{D}_{\mathrm{c}}$ (equation 3) was 0.06 for the $1.6 \mathrm{UV}$ reactor and 0.11 for the $3.2 \mathrm{UV}$ reactor. The $\mathrm{D} / \mathrm{D}_{\mathrm{c}}$ for the $3.2 \mathrm{UV}$ reactor was beyond the range of Dean flow $\left(0.03<\mathrm{D} / \mathrm{D}_{\mathrm{c}}<0.10\right)$, but as close as possible while maintaining the same UV lamp and sleeve as the 1.6 UV reactor. $\mathrm{D} / \mathrm{D}_{\mathrm{c}}$ for the 1.6 UV reactor indicates secondary vortices were developed inside the UV reactor, which were expected to promote mixing and provided uniform processing conditions. Secondary vortices (Dean flow) were expected to be less in the 3.2 UV reactor.

\subsection{Quality of milk samples}

Average composition of RCM was $4 \pm 0.1 \%$ fat and $12.8 \pm 0.15 \%$ total solids during our experiments. SCM composition was $0.1 \%$ fat and $9.1 \%$ total solids. The average SPC of RCM was $1.1 \times 10^{4} \mathrm{CFU} / \mathrm{ml}$, whereas the average SPC for SCM was $4.2 \times 10^{3} \mathrm{CFU} / \mathrm{ml}$. Coliforms and $E$. coli were not detected in either type of milk. The $\mathrm{pH}$ of RCM and SCM at $24^{\circ} \mathrm{C}$ was $6.7-6.8$ which was within the range of normal $\mathrm{pH}(6.6$ - 6.8) for both types of milk. UV-C absorption coefficient of RCM at $254 \mathrm{~nm}$ wavelength was $220 \mathrm{~cm}^{-1}$ whereas that of SCM was $170 \mathrm{~cm}^{-1}$. The absorption coefficients of both types of milk were higher than that of fruit juices $\left(11-78 \mathrm{~cm}^{-1}\right)$ reported by Koutchma et al. (2007).

\subsection{Bacteria counts in control samples}

The cell count of control samples (inoculated samples pumped through the reactor without UV lamp turned on) of RCM with E. coli and B. cereus were 8.66 and $7.74 \log _{10}$ $\mathrm{CFU} / \mathrm{ml}$ respectively. The control samples of SCM inoculated with E. coli and B. cereus had cell counts of 7.78 and $7.25 \log _{10} \mathrm{CFU} / \mathrm{ml}$ respectively. These counts indicate the potential maximum $\log$ reduction of bacteria in the treated milk.

\subsection{General observations}

Tables 2-3 illustrate the relationships among UV reactor, $\mathrm{R}_{\mathrm{e}}$ and mean number of $\log$ reductions, for each experiment. In all four experiments, the 1.6 UV reactor had a greater mean $\log$ reduction in bacteria than the 3.2 UV reactor at the same level of $\mathrm{R}_{\mathrm{e}}$. The 1.6 UV reactor benefitted from the combination of the smaller diameter tubing which resulted in a thinner path length for the UV-C to penetrate and the Dean flow which caused secondary vortices and better mixing of the milk. With the UV reactor design limitation of using the same UV lamp and quartz glass sleeve, the 3.2 UV reactor with the near Dean flow was not able to overcome the disadvantage of the thicker path length for the UV-C to penetrate.

Of the four experiments, bacteria removal to a non-detectable level was with the $1.6 \mathrm{UV}$ reactor at $\mathrm{R}_{\mathrm{e}} \geq 532$ treating $\mathrm{SCM}$ inoculated with $E$. coli. None of the other treatments achieved the minimum requirement of $5-\log _{10}$ reduction (FDA, 2003). However, mean log reduction of 
bacteria increased with $\mathrm{R}_{\mathrm{e}}$ in each experiment, regardless of UV reactor, up to the limit of the number of bacteria present. Greater log reduction was also achieved in SCM than RCM for $E$. coli while reduction of $B$. cereus was nearly the same for both types of milk. Based on the results presented, increased $\mathrm{R}_{\mathrm{e}}$ levels in both UV reactors resulted in increased log reduction of $E$. coli cells and $B$. cereus.

\section{5. $E$. coli inactivation in RCM}

Factorial ANOVA indicated significant interaction between the main effects of UV reactor and $\mathrm{R}_{\mathrm{e}}\left(F_{(3,16)}=41.27, p<0.0001\right)$ on log inactivation of $E$. coli in RCM. The simple effect of $\mathrm{R}_{\mathrm{e}}$ was significant for each of the $1.6 \mathrm{UV}$ reactor $\left(F_{(3,8)}=110.3, p<0.0001\right)$ and $3.2 \mathrm{UV}$ reactor $\left(F_{(3,8)}=20.32, p=0.0004\right)$. For the $1.6 \mathrm{UV}$ reactor, $\log$ reduction significantly increased at each increase in $\mathrm{R}_{\mathrm{e}}$ (Table 2). For the 3.2 UV reactor, log reduction of the two higher $\mathrm{R}_{\mathrm{e}}$ levels was significantly higher than the $\log$ reduction of the two lower $\mathrm{R}_{\mathrm{e}}$ levels.

\subsection{B. cereus inactivation in $\mathrm{RCM}$}

Each of the main effects had a significant effect on log reduction of B. cereus spores in RCM. The 1.6 UV reactor had a significantly higher log reduction $\left(F_{(1,16)}=19.04, p=0.0005\right)$ than the 3.2 UV reactor (Table 2$)$. The effect of $\mathrm{R}_{\mathrm{e}}$, was also significant $\left(F_{(3,16)}=7.14 ; p=\right.$ 0.0029 ) on inactivation of $B$. cereus spores in RCM, with the lowest $R_{e}$ of 181 having a significantly lower log reduction than the two higher $R_{e}$ levels of 533 and 713 . When $R_{e}$ effects were isolated for each UV reactor, the highest $\mathrm{R}_{\mathrm{e}}$ level had a significantly higher log reduction than the lowest $\mathrm{R}_{\mathrm{e}}$ level for the 1.6 UV reactor $\left(F_{(3,8)}=5.2 ; p=0.0277\right)$ and there were no differences for the $3.2 \mathrm{UV}$ reactor $\left(F_{(3,8)}=2.09 ; n s\right)$ (Table 2$)$.

\section{7. $E$. coli inactivation in $\mathrm{SCM}$}

The interaction of main effects of UV reactor and $R_{e}$ was significant $\left(F_{(3,16)}=80.3, p<\right.$ $0.0001)$ on $\log$ inactivation of $E$. coli in SCM. The simple effect of $\mathrm{R}_{\mathrm{e}}$ was significant for each of the 1.6 UV reactor $\left(F_{(3,8)}=496.4, p<0.0001\right)$ and $3.2 \mathrm{UV}$ reactor $\left(F_{(3,8)}=13.1, p=0.0019\right)$ (Table 3). For the 1.6 UV reactor, the treated SCM at three higher $\mathrm{R}_{\mathrm{e}}$ levels had undetectable bacteria levels (highest possible reduction $=7.78 \log _{10} \mathrm{CFU} / \mathrm{ml}$ ), which was significantly better than the $\log$ reduction of the lowest $\mathrm{R}_{\mathrm{e}}$ level. This can be attributed to the significantly greater degree of mixing of SCM at higher $\mathrm{R}_{\mathrm{e}}$ of 532 than the $\mathrm{R}_{\mathrm{e}}$ of 265 . Since the highest possible $\log$ reduction was already reached at this $R_{e}$ level, the $l o g$ reductions at $R_{e}$ levels 794 and 1064 also had the same $\log$ reduction $\left(7.78 \log _{10} \mathrm{CFU} / \mathrm{ml}\right)$. For the $3.2 \mathrm{UV}$ reactor, log reduction of the highest $\mathrm{R}_{\mathrm{e}}$ levels was significantly higher than the $\log$ reduction of the two lowest $\mathrm{R}_{\mathrm{e}}$ levels (Table 3).

\subsection{B. cereus inactivation in SCM}

The interaction of main effects $U V$ reactor and $\mathrm{R}_{\mathrm{e}}$ upon $\log$ inactivation of $B$. cereus endospores in $\mathrm{SCM}$ was significant $\left(\mathrm{F}_{(3,16)}=8.69, \mathrm{p}=0.0012\right)$ (Figure 5). The simple effect of $\mathrm{R}_{\mathrm{e}}$ was significant for the $1.6 \mathrm{UV}$ reactor $\left(F_{(3,8)}=85.19, p<0.0001\right)$ with each higher level of $\mathrm{R}_{\mathrm{e}}$ having a significantly greater log reduction, except for the two highest levels of $R_{e}$ which were not significantly different (Table 3). Similarly, the simple effect of $\mathrm{R}_{\mathrm{e}}$ was significant for the $3.2 \mathrm{UV}$ reactor $\left(F_{(3,8)}=4.31, p=0.0436\right)$, with the highest $R_{\mathrm{e}}$ level yielding a significantly higher $\log$ reduction than the lowest $R_{\mathrm{e}}$ level.

\subsection{General Discussion}

Inactivation efficiency of both bacteria increased as the $\mathrm{R}_{\mathrm{e}}$ increased due to better mixing conditions inside the UV reactors. A similar inactivation pattern was not observed by Koutchma 
et al. (2007) and Franz et al. (2009) because lower exposure time resulted from increased flow rates in their reactors while exposure time was kept constant at all levels of $\mathrm{R}_{\mathrm{e}}$ in our study. Constant residence time with increased mixing likely accounted for differences in inactivation patterns when compared to the others studies. Therefore, we conclude that $\mathrm{R}_{\mathrm{e}}$ number was the main factor responsible for the magnitude of inactivation of microorganisms by ultraviolet light.

Inactivation efficiency was higher for SCM than RCM for both bacteria. The inactivation differences between SCM and RCM in both UV reactors was due to the difference between UV absorption coefficients $\left(170 \mathrm{~cm}^{-1}\right.$ for SCM and $220 \mathrm{~cm}^{-1}$ for RCM) of both types of milk. Optical absorption coefficient at $254 \mathrm{~nm}$ of RCM was higher than SCM due to higher levels of suspended fat particles. This might have contributed to the greater reduction of both the bacteria in the SCM. Matak (2004) reported that E. coli was reduced by $1.44 \operatorname{logs}$ at $20^{\circ} \mathrm{C}$ in whole milk at UV dose of $5.8 \mathrm{~mJ} / \mathrm{cm}^{2}$, residence time of $1.5 \mathrm{sec}$, and $\mathrm{R}_{\mathrm{e}}$ of $1371 \mathrm{in}$ a thin film reactor. The Dean flow within the 1.6 UV reactor yielded more reduction of $E$. coli at lower $\mathrm{R}_{\mathrm{e}}$ compared to Matak (2004) in RCM. One may anticipate fouling of tubes in coiled tube reactors over time, reducing transparency of tubing and efficiency of microbial reduction. During this study we did not face this problem because we were cleaning after each treatment. In case of regular use, fouling may be avoided by following an appropriate cleaning schedule.

The initial temperatures of both types of milk were in the range of $23-24^{\circ} \mathrm{C}$. The average increase in the final temperature of milk at the outlet of UV reactors was $4-6^{\circ} \mathrm{C}$ for $1.6 \mathrm{UV}$ reactor and $2-3^{\circ} \mathrm{C}$ for $3.2 \mathrm{UV}$ reactor. This mild increase in milk temperature should not have significantly affected inactivation of the test bacteria (Matak et al., 2005).

Throughout this study, inactivation of B. cereus endospores was lower than the E. coli $\mathrm{W}$ 1485 cells (Figures 2, 3, 4, and 5). B. cereus endospores are known to be highly heat resistant and can survive pasteurization whereas E. coli does not survive pasteurization (Marshall, 2004). Blatchley et al. (2005) found that UV inactivation kinetics of B. cereus endospores in aqueous suspensions $(0.01 \mathrm{M}$ sodium bicarbonate) was characterized by a lag in inactivation for doses up to $15-20 \mathrm{~mJ} / \mathrm{cm}^{2}$, followed by roughly first-order inactivation. Inactivation response was roughly $4 \log _{10}$ units at doses above approximately $30 \mathrm{~mJ} / \mathrm{cm}^{2}$, but tailed off at higher UV doses. In our study we could achieve maximum inactivation of $B$. cereus endospores of 2.71 logs, which was about $68 \%$ of the maximum achievable reduction (4 logs).

\section{Conclusions}

Inactivation of both the bacteria increased by increasing $\mathrm{R}_{\mathrm{e}}$ at constant residence time in both UV reactors. The 1.6 UV reactor caused higher inactivation of E. coli W1485 and B. cereus endospores than the 3.2 UV reactor. The Dean flow condition and smaller tube diameter in the 1.6 UV reactor provided adequate mixing and UV exposure, as indicated by the lower UV dose for inactivation of $E$. coli W1485 cells in milk in this study than the studies on UV treatment of milk in larger coiled tube reactors or thin film reactors that were not Dean flow.

Inactivation efficiency of E.coli cells was higher for SCM than RCM with both the UV reactors. B. cereus endospores showed more resistant to UV dose than the E.coli W 1485 cells in both types of milk. E. coli $\mathrm{W} 1485$ in SCM was inactivated by more than target level of 5- $\log _{10}$ reductions whereas in RCM it was close (4.14 logs). Further, it may be possible to get FDA acceptable reduction ( $\geq 5 \log _{10}$ reductions) of $E$. coli in RCM by increasing the UV dose (residence time) in the 1.6 UV reactor. Higher thickness of milk requires better mixing 
conditions. Therefore $E$. coli inactivation in $3.2 \mathrm{UV}$ reactor may be achieved by increasing Reynolds number, residence time, or a redesign to provide Dean flow.

\section{Acknowledgements}

This project was supported by the Office of Vice Chancellor of Research through the Office of Research and Development Administration, Southern Illinois University, Carbondale, IL. Peristaltic pump was provided by Dr. M. Mohanty, Professor of Mining Engineering. Raw cow milk was provided by the SIUC Dairy Farm.

\section{References}

IFT (1999). UV light provides alternative to heat pasteurization of juices. Food Technology 53(9), 144.

Bachmann, B.J. (1972). Pedigrees of some mutant strains of E.coli K-12. Bacteriological Reviews 36: 525-557.

Bakshi, A.S., \& Smith, D.E. (1984). Effect of fat content and temperature on viscosity in relation to pumping requirements of fluid milk products. Journal of Dairy Science 67 (6), 1157-1160.

Bandla S. (2010). Design of Dean flow ultraviolet (UV) reactors and testing their efficacy for inactivation of Escherichia coli W 1485 and Bacillus cereus spores in milk. M.S. Thesis, Southern Illinois University Carbondale, IL.

Bank, H.L., Schmehl, J.L., \& Dratch, R.J. (1990). Bacteriocidal effectiveness of modulated UV light. Applied and Environmental Microbiology 56, 3888-3889.

Beuchat, L.R., Clavero, R,S., \& Jaquette, C.B. (1997). Effects of nisin and temperature on survival, growth, and enterotoxin production charcterstics of psychrotrophic Bacillus cereus in beef gravy. Applied and Environmental Microbiology 63 (5), 1953-1958.

Blatchley III, E.R., Meeusen, A., Aronson, A.I., and Brewster. L. 2005. Inactivation of Bacillus spores by ultraviolet or gamma radiation. Journal of Environmental Engineering 1245-1252.

Buchin, S., Delague, V., Duboz, G., Berdague, J.L., Beuvier, E., Pochet, S., \& Grappin, R. (1998). Influence of pasteurization and fat composition of milk on the volatile compounds and flavor characteristics of a semi-hard cheese. Journal of Dairy Science 81, 3097-3108.

Dean, W.R. (1927). Note on the motion of fluid in a curved pipe. Philosophical Magazine 5, 208223.

Donovan, K.O. (1958). A selective medium for Bacillus cereus in milk. Journal of Applied Bacterial Technology 21 (1), 100-103.

FDA (2003). Guidance for Industry: The Juice HACCP Regulation - Questions and Answers. Available at 
http://www.fda.gov/Food/GuidanceComplianceRegulatoryInformation/GuidanceDocuments/ Juice/ucm072602.htm\#k accessed May 13, 2011.

Franz, C.M.A.P., Specht, I., Cho, G.S., Graef, V., \& Stahl, M.R. (2009). UV-C inactivation of microorganisms in naturally cloudy apple juice using novel inactivation equipment based on dean vortex technology. Food Control 20, 1103-1107.

Geveke, D. J. (2005). UV Inactivation of bacteria in apple cider. Journal of Food Protection 68(8), 1739-1742.

Geveke, D.J. (2008). UV inactivation of E. coli in liquid egg white. Food and Bioprocess Technology 1, 201-206.

Grappin, R., \& Beuvier, E. (1997). Possible implication of milk pasteurization on the manufacture and sensory quality of ripened cheese. International Dairy Journal 7, 751-761.

Hanes, D.E., Orlandi, P.A., Burr, D.H., Miliotis, M.D., Robi, M.G., Bier, J.W., Jackson, G.J., Arrowood, M.J., Churey, J.J., \& Worobo, R.W. (2002). Inactivation of Cryptosporidium parvum oocysts in fresh apple cider using ultraviolet irradiation. Applied and Environment Microbiology 68, 4168-4172.

Int. Soc. for Infectious Diseases. (2006). E. coli O157, Unpasteurized milk - USA (California) (03). A ProMED-mail post, Sept. 29, 2006.

Geankoplis, C.J. (1993). Transport processes and unit operations. Prentice Hall, Englewood Cliffs, New Jersey.

Harm, W. (1980). Biological effect of ultraviolet radiation (IUPAB Biophysics Series). Cambridge University Press.

Knorr, D. (1999). Novel approaches in food processing technology: new technologies for preserving foods and modifying function. Current Opinion in Biotechnology 10, 485-491.

Koutchma, T., Keller, S., Chirtel, S., \& Parisi, B. (2004). Ultraviolet disinfection of juice products in laminar and turbulent flow reactors. Innovative Food Science and Emerging Technologies 5, 179-189.

Koutchma, T., Parisi, B., \& Patazca, E. (2007). Validation of UV coiled tube reactor for fresh juices. Journal of Environmental Engineering Science 6, 319-328.

Krishnamurthy, K., Demirci A., \& Irudayaraj, J. (2007). Inactivation of Staphylococcus aureus in milk using flow-through pulsed UV-light treatment system. Journal of Food Science 72 (7) M233-M239. 
Magnusson, M., Christiansson, A. \& Svensson, B. (2007). Bacillus cereus spores during housing of dairy cows: Factors affecting contamination of raw milk. Journal of Dairy Science 90(6), 2745-2754.

Marshall, R.T. (2004). Standard Methods for the Examination of Dairy Products, (17th ed., American Public Health Association, Washington, DC.

Matak, K.E. (2004). Effects of UV irradiation on the reduction of bacterial pathogens and chemical indicators of milk. Ph.D. dissertation, Virginia Polytechnic Institute and State University, Blacksburg, VA.

Matak, K.E., Churey, J.J., Worobo, R.W., Sumner, S.S., Hovingh, E., Hackney, C.R., \& Pierson, M.D. (2005). Efficacy of UV light for the reduction of Listeria monocytogenes in goat's milk. Journal of Food Protection 68, 2212-2216.

Miller, R., Jeffrey, W., Mitchell, D., \& Elasri, M. (1999). Bacterial responses to ultraviolet light. American Society for Microbiology News 65, 534-541.

Murakami, E.G., Jackson. L., Madsen, K., \& Schickedanz, B. (2005). Factors affecting the ultraviolet inactivation of Escherichia coli K-12 in apple juice and a model system. Journal of Food Process Engineering 29 (1), 53-71.

O'Rourke, N., L. Hatcher, \& E. J. Stepanski. 2005. A Step-by-Step Approach to Using SAS for Univariate \& Multivariate Statistics, Second Edition. SAS Institute, Inc: Cary, NC.

Quintero-Ramos, A., Churey J.J., Hartman, P., Barnard J., \& Worobo, R.W. (2004). Modeling of Escherichia coli inactivation by $\mathrm{UV}$ irradiation at different $\mathrm{pH}$ values in apple cider. Journal of Food Protection 67(6), 1153-1156.

Reinemann, D.J., Gouws, P., Cilliers, T., Houck, K., \& Bishop, J.R. (2006). New methods for UV treatment of milk for improved food safety and product quality. ASABE Paper No. 066088. St. Joseph, Mich.: ASABE.

SAS. (2008). SAS for Windows 9.2. SAS Institute Inc., Cary, NC, USA.

Wehr, H.M., \& Frank, J.F. (2004). Standard methods for the examination of dairy products. American Public Health Asociation, Washington, DC.

Wirjantoro, T.I., \& Lewis, M.J. (1997). Effect of nisin and high temperature pasteurization on shelf life of whole milk. Journal of Society of Dairy Technology 49, 99-102.

Wright, J.R., Sumner, S.S., Hackney, C.R., Pierson, M.D.,, \& Zoecklein, B.W. (2000). Efficacy of ultraviolet light for reducing Escherichia coli $\mathrm{O} 157: \mathrm{H} 7$ in unpasteurized apple cider. Journal of Food Protection 63, 563-567. 


\section{Figure Captions}

554

555

Figure 1. Diagram of coiled tube UV reactors designed for this study (drawing not to scale). For

556 the 1.6 UV reactor, the inside diameter of fluid carrying PFA tube was $1.6 \mathrm{~mm}$, whereas for the

$5573.2 \mathrm{UV}$ reactor, it was $3.2 \mathrm{~mm}$.

558

559 


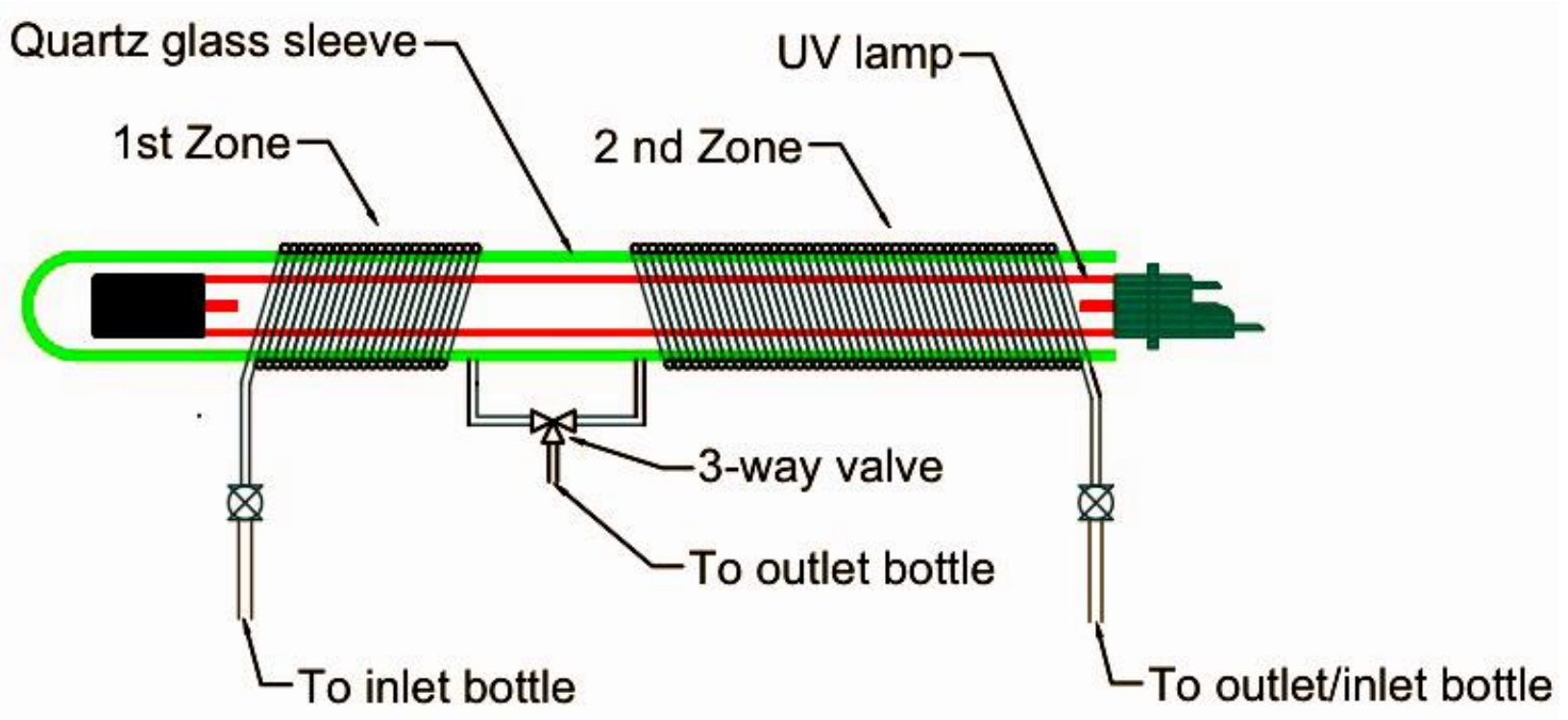

561

564

565
Figure 1. Diagram of coiled tube UV reactors designed for this study (drawing not to scale). For the 1.6 UV reactor, the inside diameter of fluid carrying PFA tube was $1.6 \mathrm{~mm}$, whereas for the $3.2 \mathrm{UV}$ reactor, it was $3.2 \mathrm{~mm}$. 


\begin{tabular}{ccccccc}
\hline & \multicolumn{2}{c}{ 1.6 UV Reactor } & \multicolumn{2}{c}{3.2 UV Reactor } & \multicolumn{2}{c}{ Mean Re } \\
\cline { 2 - 7 } $\mathrm{R}_{\mathrm{e}}$ & $\begin{array}{c}\text { Flow Rate } \\
\text { Level }\end{array}$ & $\begin{array}{c}\text { Tubing Length } \\
(\mathrm{cm})\end{array}$ & $\begin{array}{c}\text { Flow Rate } \\
(\mathrm{ml} / \mathrm{min})\end{array}$ & $\begin{array}{c}\text { Tubing Length } \\
(\mathrm{cm})\end{array}$ & $\begin{array}{c}\text { Raw Cow } \\
\text { Milk (RCM) }\end{array}$ & $\begin{array}{c}\text { Skimmed } \\
\text { Cow Milk } \\
(\mathrm{SCM})\end{array}$ \\
\hline 1 & 25 & 240 & 50 & 120 & 181 & 265 \\
2 & 50 & 480 & 100 & 240 & 359 & 532 \\
3 & 75 & 720 & 150 & 360 & 533 & 794 \\
4 & 100 & 960 & 200 & 480 & 713 & 1064 \\
\hline
\end{tabular}

Mean $\mathrm{R}_{\mathrm{e}}$ values were calculated from observed flow rates during experiments. $\mathrm{R}_{\mathrm{e}}$ values at each

$\mathrm{R}_{\mathrm{e}}$ level were same for both the reactors while they differed for each milk type due to the difference in kinematic viscosity of RCM and SCM. The residence time in each reactor was 11.3 $\mathrm{s}$ and accordingly the calculated UV doses provided were also fixed $\left(11.187 \mathrm{~mJ} / \mathrm{cm}^{2}\right)$. 
570 Table 2. Simple effects of $\mathrm{R}_{\mathrm{e}}$ within each UV reactor upon inactivation of E. coli and B. cereus 571 endospores in RCM.

572

\begin{tabular}{ccccc}
\hline & \multicolumn{2}{c}{1.6 UV Reactor } & \multicolumn{2}{c}{3.2 UV Reactor } \\
Re & E. coli* $^{*}$ & B. cereus* $^{*}$ & E. coli* & B. cereus* \\
\hline 181 & $1.37^{\mathrm{a}}$ & $1.28^{\mathrm{a}}$ & $0.46^{\mathrm{a}}$ & $1.06^{\mathrm{a}}$ \\
359 & $2.06^{\mathrm{b}}$ & $1.96^{\mathrm{ab}}$ & $0.63^{\mathrm{a}}$ & $1.19^{\mathrm{a}}$ \\
533 & $2.95^{\mathrm{c}}$ & $2.26^{\mathrm{ab}}$ & $0.97^{\mathrm{b}}$ & $1.38^{\mathrm{a}}$ \\
713 & $4.14^{\mathrm{d}}$ & $2.65^{\mathrm{b}}$ & $1.19^{\mathrm{b}}$ & $1.72^{\mathrm{a}}$ \\
\hline
\end{tabular}

* Within each bacteria and UV reactor, $\mathrm{R}_{\mathrm{e}}$ means with same letter are not significantly different

573

574 
575 Table 3. Simple effects of $\mathrm{R}_{\mathrm{e}}$ within each UV reactor upon inactivation of E. coli and B. cereus 576 endospores in SCM.

577

\begin{tabular}{ccccc}
\hline & \multicolumn{2}{c}{1.6 UV Reactor } & \multicolumn{2}{c}{3.2 UV Reactor } \\
Re & E. coli* $^{*}$ & B. cereus* & E. coli* $^{*}$ & B. cereus* $^{*}$ \\
\hline 265 & $2.06^{\mathrm{a}}$ & $1.59^{\mathrm{a}}$ & $0.47^{\mathrm{a}}$ & $1.29^{\mathrm{a}}$ \\
532 & $7.78^{\mathrm{b}}$ & $2.23^{\mathrm{b}}$ & $1.12^{\mathrm{a}}$ & $1.34^{\mathrm{ab}}$ \\
794 & $7.78^{\mathrm{b}}$ & $2.57^{\mathrm{c}}$ & $1.45^{\mathrm{ab}}$ & $1.46^{\mathrm{ab}}$ \\
1064 & $7.78^{\mathrm{b}}$ & $2.72^{\mathrm{c}}$ & $2.43^{\mathrm{b}}$ & $1.78^{\mathrm{b}}$ \\
\hline
\end{tabular}

* Within each bacteria and UV reactor, $\mathrm{R}_{\mathrm{e}}$ means with same letter are not significantly different 


$\begin{array}{lll}580 & \text { Nomenclature } & \\ 581 & \text { B.cereus } & \text { Bacillus cereus } \\ 582 & \text { CFU } & \text { colony forming unit } \\ 583 & \text { CFU/ml } & \text { dolony forming unit per milliliter } \\ 584 & \text { D } & \text { diameter of tube coil } \\ 585 & \text { Dc } & \text { Dean number } \\ 586 & \text { De } & \text { Escherichia coli } \\ 587 & \text { E.coli } & \text { inside diameter } \\ 588 & \text { ID } & \text { dynamic viscosity of fluid (milk) } \\ 589 & \mu & \text { milli joule per square centimeter } \\ 590 & \text { mJ/cm } & \text { milliliter per minute } \\ 591 & \text { ml/min } & \text { milli watt per square centimeter } \\ 592 & \text { mW/cm } & \text { mannitol egg yolk polymyxin agar } \\ 593 & \text { MYPA } & \text { nanometer } \\ 594 & \text { nm } & \text { outside diameter } \\ 595 & \text { OD } & \text { per-fuoro-alkoxy } \\ 596 & \text { PFA } & \text { density of fluid (milk) } \\ 597 & \rho & \text { raw cow milk } \\ 598 & \text { RCM } & \text { Reynolds number } \\ 599 & \text { Re } & \text { skimmed cow milk } \\ 600 & \text { SCM } & \text { standard plate count } \\ 601 & \text { SPC } & \text { tryptic soy agar } \\ 602 & \text { TSA } & \text { tryptic soy broth } \\ 603 & \text { TSB } & \text { ultraviolet } \\ 604 & \text { UV } & \text { ultraviolet C } \\ 605 & \text { UV-C } & \text { velocity of fluid flow } \\ 606 & \text { v } & \text { volt } \\ 607 & \text { V } & \text { Watt } \\ 608 & \text { W } & \\ 609 & & \end{array}$

